\title{
Huaier Aqueous Extract Induces Hepatocellular Carcinoma Cells Arrest in S Phase via JNK Signaling Pathway
}

\author{
Chengshuo Zhang, ${ }^{1}$ Jialin Zhang, ${ }^{1}$ Xin Li, ${ }^{2}$ Ning Sun, ${ }^{1}$ Rui Yu, ${ }^{1}$ Bochao Zhao, \\ Dongyang Yu, ${ }^{3}$ Ying Cheng, ${ }^{1}$ and Yongfeng Liu ${ }^{1}$ \\ ${ }^{1}$ Department of Hepatobiliary Surgery and Unit of Organ Transplantation, First Hospital of China Medical University, \\ 155 Nanjingbei Street, Heping District, Shenyang 110001, China \\ ${ }^{2}$ Department of General Surgery, Fourth Hospital of China Medical University, 4 Chongshandong Road, Huanggu District, \\ Shenyang 110032, China \\ ${ }^{3}$ Department of Gastrointestinal Surgery, First Hospital of China Medical University, 155 Nanjingbei Street, Heping District, \\ Shenyang 110001, China \\ Correspondence should be addressed to Jialin Zhang; jlz2000@yeah.net
}

Received 21 August 2014; Revised 12 November 2014; Accepted 12 November 2014

Academic Editor: Qing He

Copyright ( $) 2015$ Chengshuo Zhang et al. This is an open access article distributed under the Creative Commons Attribution License, which permits unrestricted use, distribution, and reproduction in any medium, provided the original work is properly cited.

\begin{abstract}
Huaier aqueous extract, the main active constituent of Huaier proteoglycan, has antihepatocarcinoma activity in experimental and clinical settings. However, the potential and associated antihepatoma mechanisms of Huaier extract are not yet fully understood. Therefore, in this study, we aimed to elucidate the inhibitory proliferation effect of Huaier extract on apoptosis and cycle of HepG2 and Bel-7402 cells. Our data demonstrated that incubation with Huaier extract resulted in a marked decrease in cell viability dosedependently. Flow cytometric analysis showed that a $48 \mathrm{~h}$ treatment of Huaier extract caused cell apoptosis. Typical apoptotic nucleus alterations were observed with fluorescence microscope after Hoechst staining. Immunoblot analysis further demonstrated that Huaier extract activated caspase 3 and PARP. Additionally, Huaier extract inhibited the activity of p-ERK, p-p38, and p-JNK in terms of MAPK. Furthermore, Huaier extract induced HCC cells arrest in S phase and decreased the cycle related protein expression of $\beta$-catenin and cyclin D1. Studies with JNK specific inhibitor, SP600125, showed that Huaier extract induced S phase arrest and decreased $\beta$-catenin and cyclin D1 expression via JNK signaling pathway. In conclusion, we verify that Huaier extract causes cell apoptosis and induces hepatocellular carcinoma cells arrest in S phase via JNK pathway, which advances our understanding on the molecular mechanisms of Huaier extract in hepatocarcinoma management.
\end{abstract}

\section{Introduction}

Hepatocellular carcinoma (HCC) is the fifth most frequent malignancy and the second leading fatal disease worldwide [1]. There are several canonical strategies for hepatocellular carcinoma treatment, including surgical resection, local ablation, liver transplantation, radiotherapy, chemotherapy, and molecular targeted therapy [2-4]. However, these treatments cause serious side effects sometimes; they are not applicable to all of the patients and demonstrate to be of limited efficacy $[5,6]$. Therefore, identification of novel antitumor agents from natural products with better effectiveness is an alternative choice for management of hepatocellular carcinoma.
In recent years, many Chinese herbs have been gradually discovered to be potential sources of antitumor drugs for its role in killing tumor cells less intensively and more naturally $[7,8]$. Trametes robiniophila Murr. (Huaier) has been applied in traditional Chinese medicine for approximately 1600 years [9]; however, its antitumor properties are found and used as a complementary therapy only in recent decades. The main effective ingredient of this officinal fungi has been identified as proteoglycan which contains $41.53 \%$ polysaccharides, $12.93 \%$ amino acids, and $8.72 \%$ water [10]. A number of studies have demonstrated that Huaier extract inhibited proliferation and induced apoptosis in pulmonary cancer, breast cancer, melanoma, and colorectal cancer [11-14]. In 
addition, Huaier extract has also been indicated as a suppressant in angiogenesis and cell motility of ovarian cancer $[6,15]$. The accumulating evidences have demonstrated that Huaier extract dose-dependently inhibited the proliferation, adhesion, migration, invasion, and angiogenesis and induced apoptosis of hepatoma cells [16, 17]. However, the underlying molecular mechanisms of Huaier extract activities in hepatocellular carcinoma cells are not yet fully understood.

Cell cycle deregulation, resulting in uncontrolled cell proliferation, is one of the most common alterations that occur during tumor development. Therefore, cell cycle arrest is considered to be an effective strategy for eliminating cancer cells [18]. Two major checkpoints, one at the G1/S transition and the other at the G2/M transition, regulate the cell cycle and, therefore, the modulated expression of cell cycle regulatory molecules on antiproliferation has been investigated in numerous cell types [19]. A general critical event associated with DNA damage is the activation of cell cycle checkpoints and cycling and cyclic-dependent kinases (cdks) are evolutionarily conserved proteins that are essential for cell cycle control [20]. Distinct pairs of cyclins and cdks regulate the progression through the various stages of the cell cycle; cdk activity is regulated by cyclins, which bind to and activate cdks [21]. Among these cyclins, cyclin D1 is regarded as an oncogene and is a major driver of multiple types of human tumors including breast and squamous cell cancers, B-cell lymphoma, myeloma, and parathyroid adenoma [22]. In addition to cyclin D1 and its upstream effector $\beta$-catenin [23], the mitogen-activated protein kinase (MAPK) superfamily members are also associated with increased migration, invasion, proliferation, survival, and apoptosis, thus serving different roles in cellular responses [23]. ERK1/2, p38 MAPK, and JNK/SAPK have been reported to play a central role in the regulation of $\beta$-catenin and cyclin D1 expression [24].

Little is known about the molecular mechanisms responsible for the proliferative properties of Huaier extract, and no studies have investigated the potential role of Huaier in cell proliferation of human HCC cells. Understanding the mechanism of action of Huaier extract should provide useful information for their possible application in cancer therapy and cancer prevention. Therefore, in this study we mainly aim to explore the antiproliferation mechanisms of Huaier extract in HCC cells.

\section{Materials and Methods}

2.1. Preparation of Huaier Aqueous Extract. Huaier electuary ointment was a gift from Gaitianli Pharmaceutical Co., Ltd. (Qidong, Jiangsu, China). Two grams of the electuary ointment was dissolved in $20 \mathrm{~mL}$ of complete medium and was sterilized with $0.22 \mu \mathrm{m}$ filter to get the $100 \mathrm{mg} / \mathrm{mL}$ stock solution for long storage at $-20^{\circ} \mathrm{C}[25]$.

2.2. Cell Culture. HCC cell lines, including HepG2 and Bel7402, were grown in RPMI 1640 medium (Gibco, USA) in the presence of $10 \%$ fetal bovine serum (Gibco, USA) and incubated in a humidified atmosphere containing 5\% $\mathrm{CO}_{2}$ at $37^{\circ} \mathrm{C}$. Immortalized normal liver epithelial cells,
THLE-3, were maintained in Dulbecco's modified Eagle's medium (DMEM) (Invitrogen, Carlsbad, CA) supplemented with $100 \mathrm{U} / \mathrm{mL}$ penicillin and $100 \mu \mathrm{g} / \mathrm{mL}$ streptomycin in the presence of $10 \%$ fetal bovine serum and incubated in a humidified atmosphere containing $5 \% \mathrm{CO}_{2}$ at $37^{\circ} \mathrm{C}$.

2.3. Cell Proliferation Assay. Cell proliferation was measured using the CellTiter 96 Aqueous One Solution cell proliferation assay (Promega, Madison, WI, USA). Cells were seeded in 96-well plates at a concentration of $10^{4}$ cells/well, allowed to adhere for $24 \mathrm{~h}$, and subsequently exposed to different concentrated solutions as indicated below. Proliferation viability was measured according to the manufacturer's instructions after $48 \mathrm{~h}$. The absorbance value at $490 \mathrm{~nm}$ was measured with an ELISA reader (BioTek, Vermont, USA). The stock solution of Huaier extract was diluted at final concentrations of $0,2,4$, 8 , and $16 \mathrm{mg} / \mathrm{mL}$ with complete 1640 medium. The viability ratio was calculated according to the following formula: The Viability Ratio $=[$ (the absorbance of experimental group the absorbance of blank group)/(the absorbance of untreated group - the absorbance of blank group)] $\times 100 \%$.

2.4. Apoptosis Assay. Cell apoptosis was determined using the Annexin V-FITC apoptosis detection kit (Bio-science, Beijing, China). Briefly, $2 \times 10^{5}$ cells were seeded into a 6 well plate. After $48 \mathrm{~h}$ exposure to different concentrations of Huaier aqueous extract as above, all the adherent cells were collected with $0.25 \%$ trypsin without EDTA, including the floating cells in the medium. Annexin V-FITC and propidium iodide (PI) were used for staining according to the manufacturer's instructions. The double-stained cells were subsequently analyzed by a FACSCanto flow cytometer (Becton-Dickinson, Mountain View, CA, USA). At least 10,000 cells were counted each time.

2.5. Hoechst 33258 Staining. Following treatment with Huaier extract at various concentrations for up to $48 \mathrm{~h}$ in a 6 -well plate, cells were washed twice with PBS and fixed in $1 \mathrm{~mL}$ of $4 \%$ paraformaldehyde for $10 \mathrm{~min}$ at $4^{\circ} \mathrm{C}$. After washing twice with PBS, cells were stained with $500 \mu \mathrm{L}$ Hoechst 33258 (Beyotime, Haimen, China) for $15 \mathrm{~min}$ at room temperature in the dark and then washed with PBS. Afterwards, the cells were mounted and examined under fluorescence microscopy (Olympus IX71, Tokyo, Japan). Apoptotic cells were identified by the condensation and fragmentation of their nucleus. The apoptotic ratio was obtained by the following calculation: The Apoptotic Ratio = apoptotic cell number/seeded cell number $\times 100 \%$.

2.6. Cell Cycle Assay. Briefly, $2 \times 10^{5}$ cells were seeded into a 6-well plate and starved in serum-free medium on the second day. After $12 \mathrm{~h}$ starvation, the cells were treated with gradient concentrations of Huaier solution for $48 \mathrm{~h}$. The cells were then trypsinized, washed with cold PBS, and fixed overnight with $70 \%$ cold ethanol at $4^{\circ} \mathrm{C}$. The next day, the fixed cells were centrifuged at $1200 \mathrm{~g}$ for $5 \mathrm{~min}$ and washed once with PBS. After that, the cells were suspended in PI/RNase staining buffer for 
$30 \mathrm{~min}$ in the dark according to the manufacturer's instructions of Cell Cycle Detection Kit (KeyGEN, Nanjing, China). Then, the DNA contents of the cells were analyzed in a FACScan flow cytometer (Becton Dickenson, San Jose, CA, USA). At least 10,000 cells were collected for each measurement.

2.7. Western Blot Analysis. The cells treated with Huaier extract or SP600125 (a JNK1/2 inhibitor, Beyotime, Haimen, China) for $48 \mathrm{~h}$ were washed twice with ice-cold PBS and lysed in ice-cold protein lysis buffer supplemented with $1 \%(\mathrm{v} / \mathrm{v})$ protease inhibitor cocktail and PMSF. The lysates were centrifuged at $12,000 \mathrm{rpm}$ for $10 \mathrm{~min}$ at $4^{\circ} \mathrm{C}$. The suspension protein concentrations were determined using a BCA Protein Assay kit (Beyotime, Haimen, China) and were then denatured by boiling. Total proteins $(25 \mu \mathrm{g} / \mathrm{lane})$ were resolved onto SDS-PAGE and transferred onto a PVDF membrane in a wet transfer system (Bio-Rad, USA) at $70 \mathrm{~V}$ at $4^{\circ} \mathrm{C}$. For immunoblotting, the PVDF membrane was incubated with Tris-buffered saline plus Tween-20 (TBS-T) containing $5 \%$ nonfat milk for $1.5 \mathrm{~h}$ and then incubated with a specific primary antibody overnight at $4^{\circ} \mathrm{C}$. Horseradish peroxidase- (HRP-) conjugated IgG was used as the secondary antibody and incubated for $2 \mathrm{~h}$. Afterwards, reactive protein was detected using an enhanced chemiluminescence (ECl) commercial kit (Beyotime, Beijing, China). The results were recorded using the MicroChemi Bio-Imaging Systems (DNR Bio-Imaging Systems Ltd, Jerusalem, Israel) and Quantity One version 4.5.0 software (Bio-Rad, Hercules, CA, USA).

The primary antibodies used in this study were as follows: rabbit anti-pro-caspase 3 polyclonal antibody (Cat no. 196771-AP; Proteintech Group, Inc. Chicago, IL, USA), rabbit anti-cleaved-caspase 3 polyclonal antibody (Cat no. 255461-AP; Proteintech Group), rabbit anti- $\beta$-catenin polyclonal antibody (Cat no. 51067-2-AP; Proteintech Group), mouse anti-cyclin D1 monoclonal antibody (Cat no. 60186-1-Ig; Proteintech Group), mouse anti-GAPDH monoclonal antibody (Cat no. 60004-1-lg; Proteintech Group), rabbit anti-ERK polyclonal antibody (Cat no. 94; Santa Cruz Biotechnology, Inc., Santa Cruz, CA, USA), rabbit anti-p38MAPK polyclonal antibody (Cat no. 535; Santa Cruz Biotechnology), rabbit anti-JNK polyclonal antibody (Cat no. 571; Santa Cruz Biotechnology), mouse anti-pERK monoclonal antibody (Cat no. 7383; Santa Cruz Biotechnology), mouse antipp38MAPK monoclonal antibody (Cat no. 7973; Santa Cruz Biotechnology), mouse anti-pJNK monoclonal antibody (Cat no. 6254; Santa Cruz Biotechnology), and mouse anti-tubulin monoclonal antibody (Cat no. 0098; Cwbiotech, Beijing, China). The secondary antibodies included goat anti-rabbit IgG serum (1:40,000 dilution; Zhongshan Golden Bridge, Beijing, China) and goat anti-mouse IgG serum $(1: 40,000$ dilution; Zhongshan Golden Bridge).

2.8. Statistical Analysis. All experiments were performed three times. Data were presented as means \pm standard deviations (SD). The differences were analyzed using one-way ANOVA followed by the Student-Newman-Keuls test and all statistical analyses were performed using GraphPad Prism 5

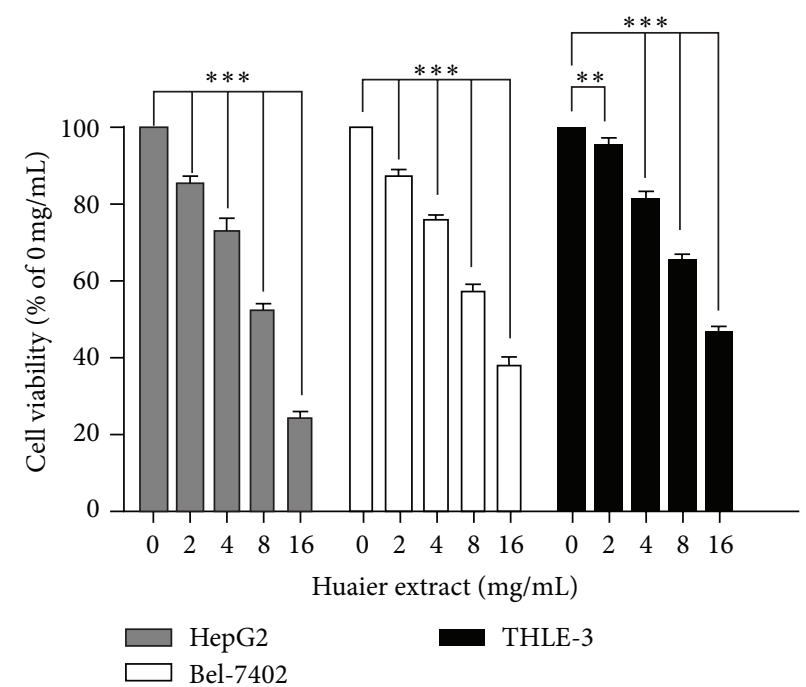

FIgURE 1: Effect of Huaier extract on the viability of HepG2, Bel-7402, and THLE-3 cells. HepG2, Bel-7402, and THLE-3 cells $\left(10^{4}\right.$ cells/well $)$ were treated with various concentrations $(0,2,4$, 8 , and $16 \mathrm{mg} / \mathrm{mL}$ ) of Huaier extract for $48 \mathrm{~h}$. Cell viability was determined by using an MTS assay. The results represent the means $\pm \mathrm{SD}$ of 3 independent experiments. ${ }^{* *} P<0.01$ and ${ }^{* * *} P<$ 0.001 , compared with that of the untreated control, respectively $(0 \mathrm{mg} / \mathrm{mL})$.

software. Statistical differences are presented at probability levels of $P<0.05, P<0.01$, and $P<0.001$.

\section{Results}

3.1. Huaier Extract Inhibits Cell Proliferative Viability of HepG2 and Bel-7402 Cells. To evaluate the proliferative effect of Huaier extract on HepG2 and Bel-7402 cells, we measured cell proliferative viability using the MTS assay after the cells were dose-dependently treated with Huaier extract for $48 \mathrm{~h}$. As shown in Figure 1, Huaier extract significantly suppressed cell viability of both HepG2 and Bel-7402 cells in a dosedependent manner with $\mathrm{IC}_{50}$ value of 7.6 and $10.6 \mathrm{mg} / \mathrm{mL}$, respectively, after $48 \mathrm{~h}$. But the $\mathrm{IC}_{50}$ value in the case of THLE- 3 was $13.8 \mathrm{mg} / \mathrm{mL}$, which means that the Huaier extract is less toxic to the normal liver cells than to HCC cells.

3.2. Huaier Extract Induces Cell Apoptosis in HepG2 and Bel7402 Cells. To demonstrate the apoptosis effect of Huaier extract, we used FCM analysis with Annexin V-FITC and PI double staining. After treatment with different doses of Huaier extract for $48 \mathrm{~h}$, early apoptotic cells and late apoptotic cells were differentiated from viable or necrotic ones. In the control group, there were almost normal cells, rarely apoptotic cells, while in Huaier extract groups, the rates of apoptotic cells gradually increased along with increasing concentrations of Huaier extract. The rates of apoptosis in different Huaier extract $(0,2,4,8$, and $16 \mathrm{mg} / \mathrm{mL})$ groups were $5.50 \pm 1.04 \%, 13.57 \pm 0.58 \%, 29.40 \pm 3.00 \%, 49.53 \pm 8.50 \%$, and $96.22 \pm 3.06 \%$, respectively, in HepG2 cells, and $1.5 \pm 0.5 \%$, 

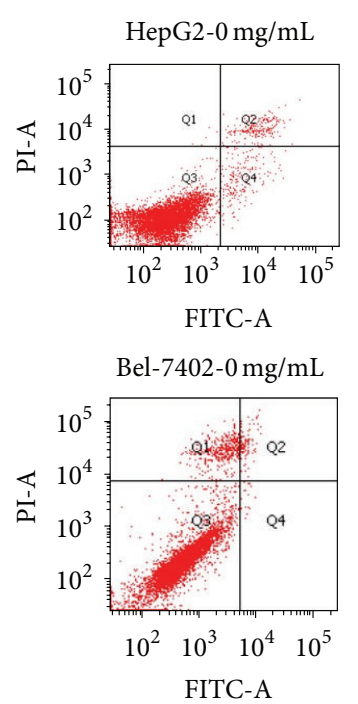
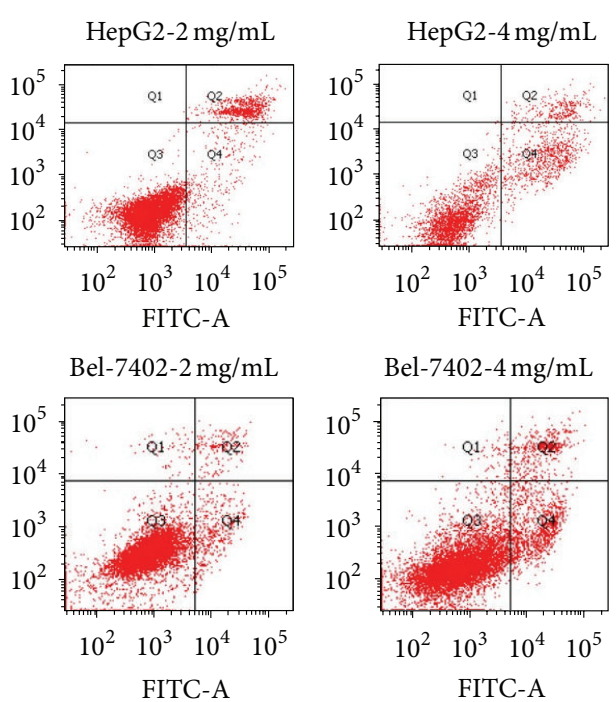

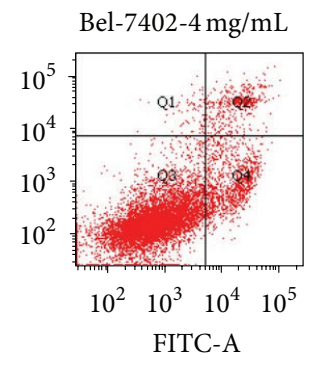

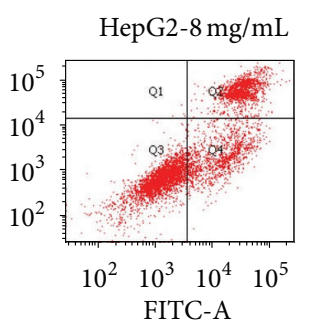

Bel-7402-8 mg/mL

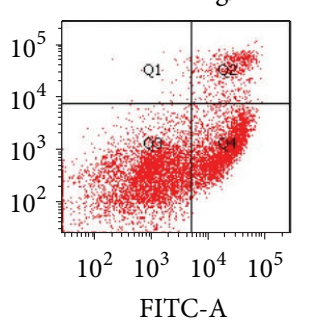

HepG2-16 mg/mL

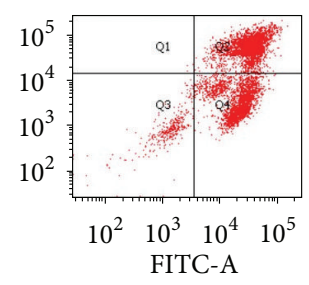

Bel-7402-16 mg/mL

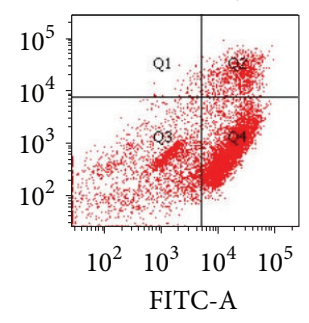

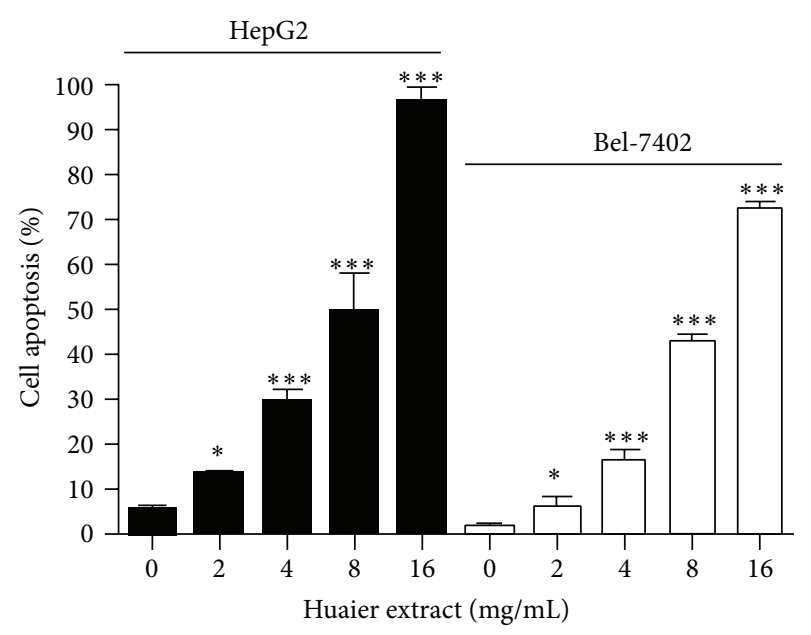

Figure 2: Effect of Huaier extract on the apoptosis of HepG2 and Bel-7402 cells. FCM analysis for apoptosis after treatment by Annexin V-FITC and PI staining on HCC cells with different doses of Huaier extract $(0,2,4,8$, and $16 \mathrm{mg} / \mathrm{mL})$ for $48 \mathrm{~h}$. The ratios are expressed as the mean ratios $\pm \mathrm{SD}$ in triplicate. ${ }^{*} P<0.05$ and ${ }^{* * *} P<0.001$, compared with that of the untreated control, respectively $(0 \mathrm{mg} / \mathrm{mL})$.

$6.1 \pm 2.1 \%, 16.6 \pm 2 \%, 43 \pm 1.5 \%$, and $72.4 \pm 1.6 \%$ respectively, in Bel-7402 cells (Figure 2).

\subsection{Huaier Extract Induces Morphological Changes in HepG2} Cells. In addition, we verified the apoptotic effect of Huaier extract in HepG2 cells by morphological changes. After treatment with different doses of Huaier extract for 48 h, HepG2 cells were stained with Hoechst 33258. The normal cells in morphology are round and homogenous, while the morphological changes of cell apoptosis include cell shrinkage, nuclear condensation, and fragmentation. Fluorescence dye stains condense chromatin of apoptotic cells more brightly than chromatin of normal cells. The number of HepG2 cells adhering to the culture plates in Huaier extract treatment was greatly reduced compared to control group. The apoptotic morphological changes were observed in the Huaier extracttreated groups, whereas few apoptotic cells were found in the control group. The percentage of apoptotic cells in different Huaier extract $(0,2,4,8$, and $16 \mathrm{mg} / \mathrm{mL})$ groups was
$4.27 \pm 1.80 \%, 14.27 \pm 1.20 \%, 27.60 \pm 2.00 \%, 33.17 \pm 1.90 \%$, and $62.67 \pm 2.40 \%$, respectively, in HepG2 cells (Figure 3 ).

3.4. Huaier Extract Activates Caspase 3 and Induces the Expression of Cleaved Caspase 3 and Cleaved PARP in HepG2 and Bel-7402 Cells. To further confirm the apoptotic mechanisms of Huaier extract on HCC cells, we tested the expression of procaspase 3, cleaved caspase 3 , and cleaved PARP with Western blot. Huaier extract activated the caspase 3 , resulting in increased expression of cleaved caspase 3, cleaved PARP, and decreased expression of procaspase 3 (Figure 4).

3.5. Huaier Extract Induces Cells Arrest in S Phase of HepG2 and Bel-7402 Cells. To further investigate the effect of Huaier extract on the cell cycle, the cell cycle profiles of HepG2 and Bel-7402 cells were analyzed using flow cytometry. The cells were treated with Huaier extract at concentrations of $0,2,4$, 8 , and $16 \mathrm{mg} / \mathrm{mL}$ for $48 \mathrm{~h}$ and stained with PI. Huaier extract 
HepG2-0 mg/mL

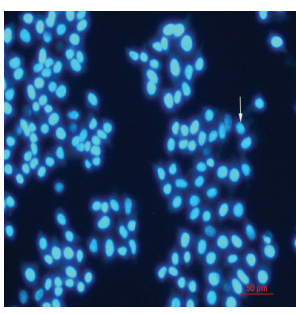

HepG2-2 mg/mL

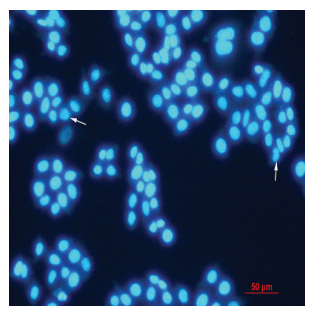

HepG2-4 mg/mL

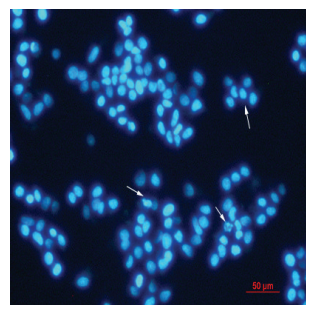

HepG2-8 mg/mL

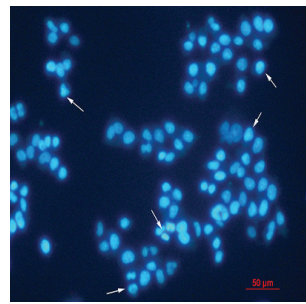

HepG2-16 mg/mL

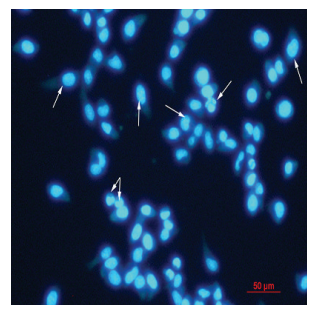

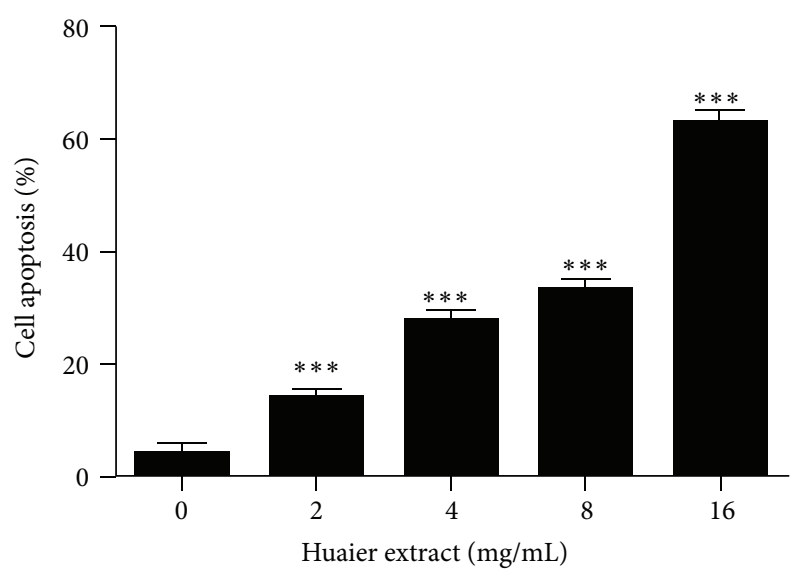

FIGURE 3: Effect of Huaier extract on the morphological changes of HepG2 cells. Hoechst 33258 staining was used to observe the apoptotic cells under a BX-60 fluorescence microscope (200x) after cells were treated with different doses of Huaier extract $(0,2,4,8$, and $16 \mathrm{mg} / \mathrm{mL})$ for $48 \mathrm{~h}$. The arrow shows apoptotic cells. The values are expressed as the mean ratios \pm SD from three independent experiments. ${ }^{* * *} P<0.001$, compared with that of the untreated control $(0 \mathrm{mg} / \mathrm{mL})$.

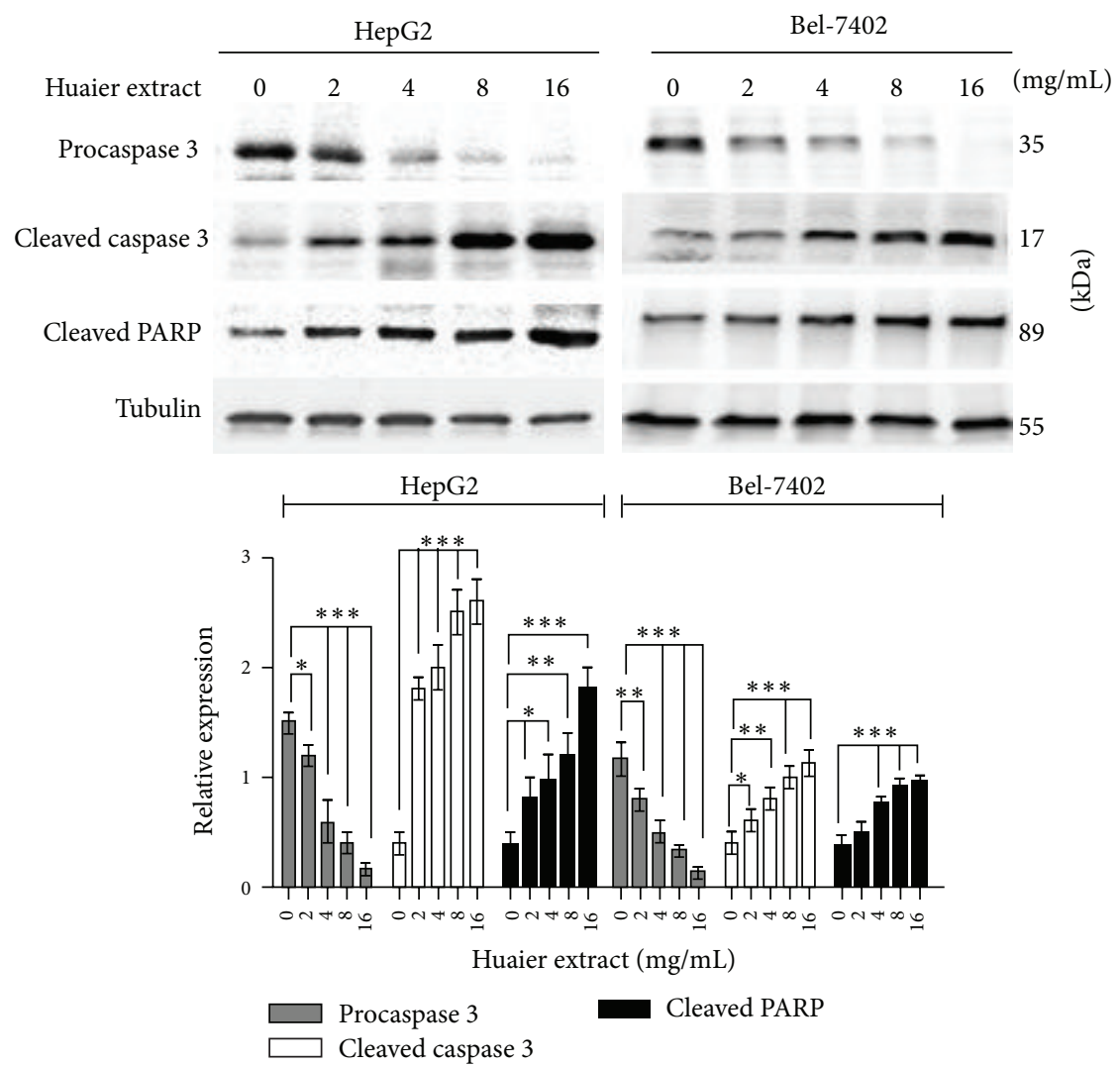

FIGURE 4: Effects of Huaier extract on expression of procaspase 3, cleaved caspase 3, and cleaved PARP in HCC cells. HCC cells were treated with various concentrations $(0,2,4,8$, and $16 \mathrm{mg} / \mathrm{mL})$ of Huaier extract for $48 \mathrm{~h}$, and then cell lysates were subjected to Western blotting with procaspase 3, cleaved caspase 3, and cleaved PARP antibodies. The densitometric ratios were normalized to those of tubulin, and the results are expressed as the mean densitometric ratios \pm SD in three independent experiments. ${ }^{*} P<0.05,{ }^{* *} P<0.01$, and ${ }^{* * *} P<0.001$, compared with that of the untreated control, respectively $(0 \mathrm{mg} / \mathrm{mL})$. 

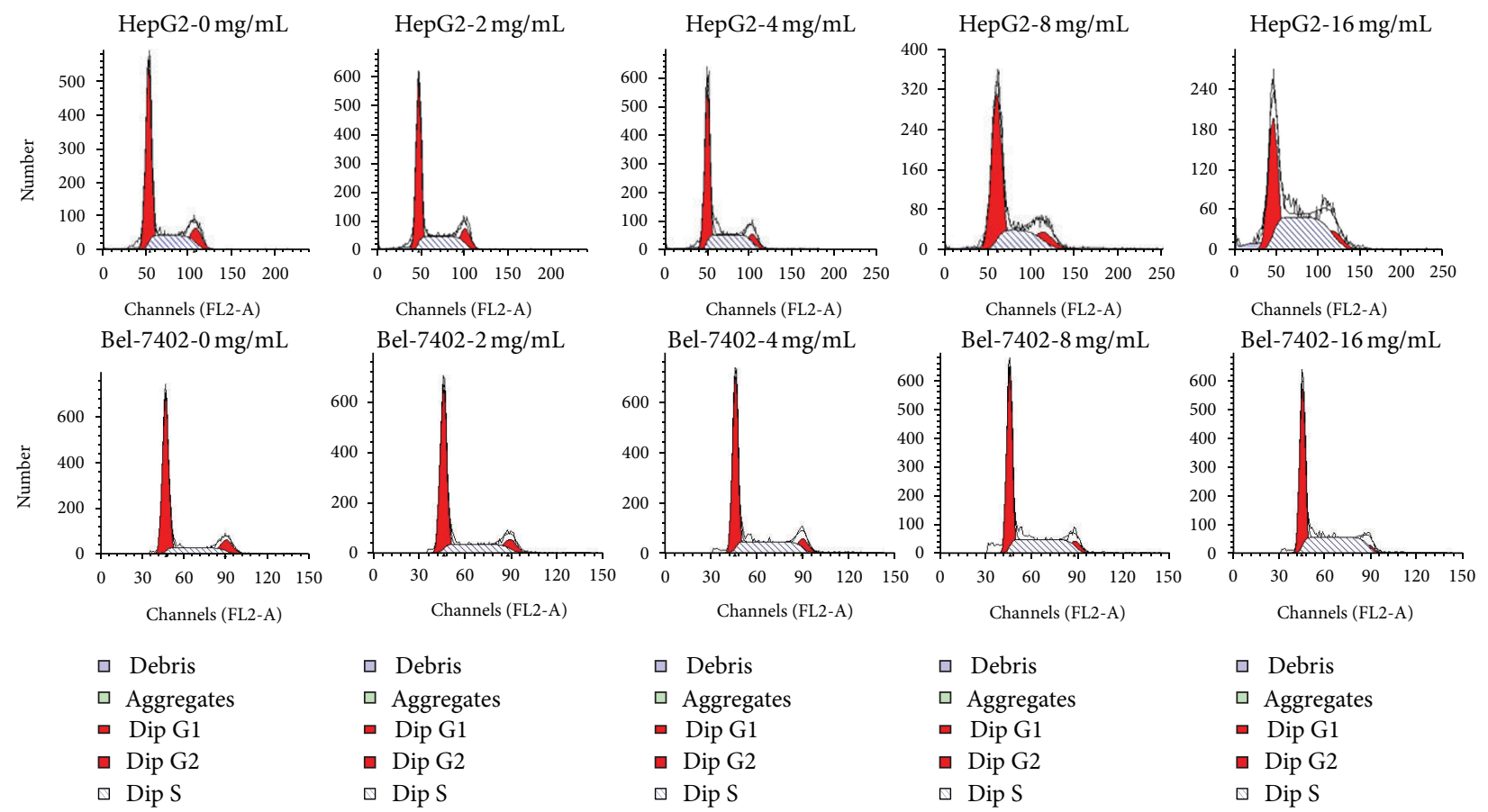

$\square$ Debris
$\square$ Aggregates
$\square$ Dip G1
$\square$ Dip G2
$\square$ Dip S

$\square$ Debris
$\square$ Aggregates
$\square$ Dip G1
$\square$ Dip G2
$\square$ Dip S

$\square$ Debris
$\square$ Aggregates
$\square$ Dip G1
$\square$ Dip G2
$\square$ Dip S

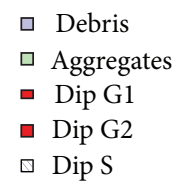

HepG2
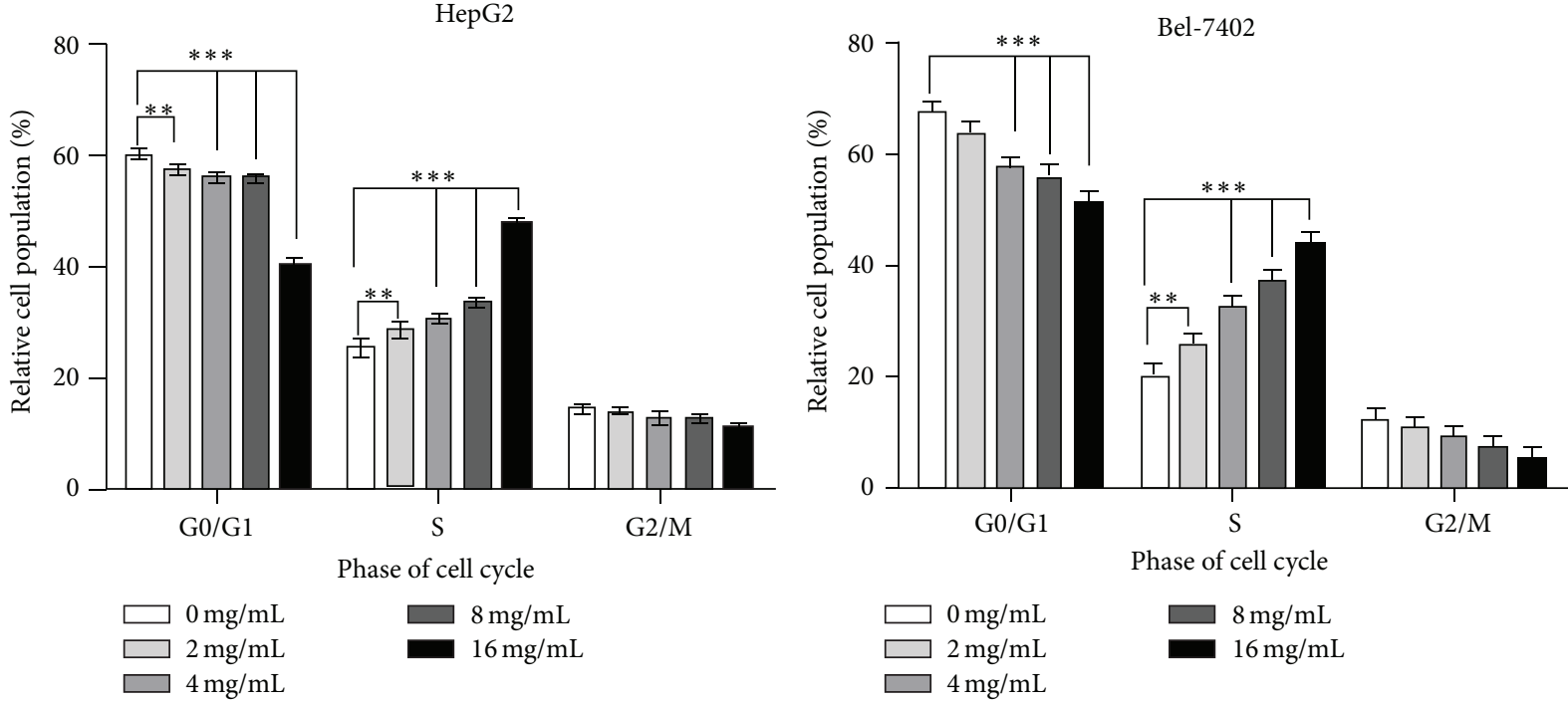

FIGURE 5: Effects of Huaier extract on the cell cycle of HCC cells by FCM. The cell cycle distributions in HepG2 and Bel-7402 cells were determined by PI staining and FCM analysis after being treated with different concentrations of Huaier extract $(0,2,4,8$, and $16 \mathrm{mg} / \mathrm{mL})$ for $48 \mathrm{~h}$. The ratios are expressed as the mean ratios \pm SD of three independent experiments. ${ }^{* *} P<0.01$ and ${ }^{* * *} P<0.001$, compared with that of the untreated control, respectively $(0 \mathrm{mg} / \mathrm{mL})$.

treatment resulted in a significant increase in the percentage of cells in the $\mathrm{S}$ phase and a significant decrease in the percentage of cells in the G0/G1 phase. The percentage of cells accumulated in the $S$ phase were $25.31 \pm 1.53 \%, 28.43 \pm 1.25 \%$, $30.48 \pm 0.76 \%, 33.55 \pm 0.81 \%$, and $47.57 \pm 0.87 \%$, respectively, in HepG2 cells, and $20.25 \pm 2.06 \%, 25.87 \pm 2.06 \%, 32.43 \pm$ $2.02,37.11 \pm 2.05$, and $43.61 \pm 2.33$, respectively, in Bel-7402 cells. The accumulation of G0/G1 phase cells was maximal in the control group and declined with increasing concentrations of Huaier extract. The decrease in the number of G0/G1 phase cells was $60.36 \pm 0.71 \%, 57.43 \pm 0.95 \%, 56.13 \pm 0.96 \%$, $55.76 \pm 0.54 \%$, and $40.38 \pm 0.88 \%$, respectively, in HepG2 cells, and $67.4 \pm 2.07,63.62 \pm 2.30,57.5 \pm 1.84,55.66 \pm 2.41$, and $51.23 \pm 2.10$, respectively, in Bel-7402 cells (Figure 5). These results indicate that Huaier extract suppresses HCC cells proliferation by inducing $S$ phase cell cycle arrest. 


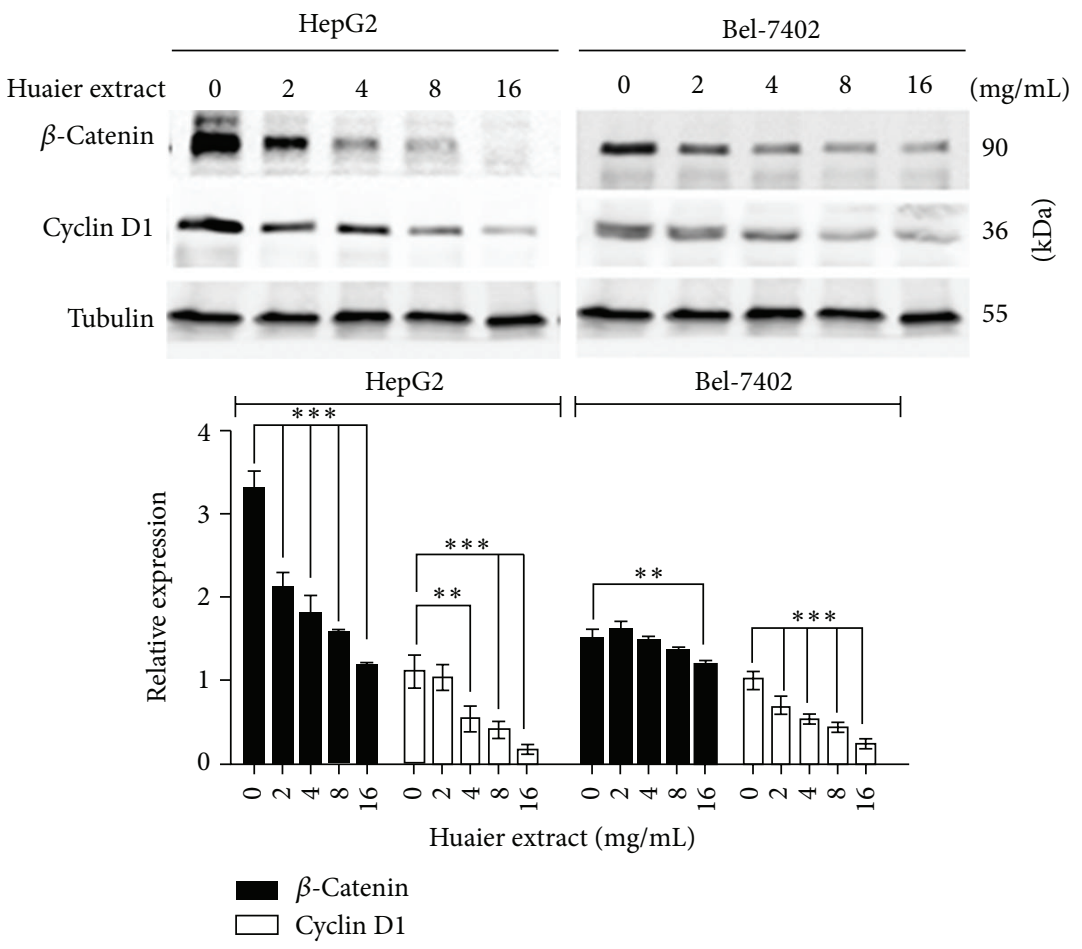

FIGURE 6: Effects of Huaier extract on expression of cycle related $\beta$-catenin and cyclin D1 in HCC cells. HCC cells were treated with various concentrations $(0,2,4,8$, and $16 \mathrm{mg} / \mathrm{mL})$ of Huaier extract for $48 \mathrm{~h}$, and then cell lysates were subjected to Western blotting with $\beta$-catenin and cyclin D1 antibodies. The densitometric ratios were normalized to those of tubulin, and the results are expressed as the mean densitometric ratios \pm SD in three independent experiments. ${ }^{* *} P<0.01$ and ${ }^{* * *} P<0.001$, compared with that of the untreated control, respectively $(0 \mathrm{mg} / \mathrm{mL})$.

3.6. Huaier Extract Inhibits Cycle Related $\beta$-Catenin and Cyclin D1 Expression in HepG2 and Bel-7402 Cells. To elucidate the underlying mechanisms responsible for the proliferative inhibitory properties of Huaier extract on HepG 2 and Bel-7402 cells, we detected changes of $\beta$-catenin and cyclin D1 expression by Western blotting and found that Huaier extract treatment significantly decreased the expression of $\beta$-catenin and cyclin D1 in a dose-dependent manner (Figure 6).

3.7. Huaier Extract Inhibits the Phosphorylation of MAPK in HCC Cells. MAPK has been shown to be involved in the induction of cycle related $\beta$-catenin and cyclin D1 in many types of cancer [24]. Given that treatment with Huaier extract inhibited expression of $\beta$-catenin and cyclin D1, we attempted to determine the MAPK related protein expression by Huaier extract treatment in HCC cells. By treating HepG2 and Bel7402 cells with various concentrations of Huaier extract, it was determined that there was a significant dose-dependent decrease in the phosphorylation of ERK1/2, p38, and JNK1/2 in HCC cells (Figure 7). This finding indicates that Huaier extract may suppress the expression of $\beta$-catenin and cyclin D1 by inactivating the MAPK pathways.

3.8. Huaier Extract Inhibits the Expression of $\beta$-Catenin and Cyclin D1 and Induces S Phase Arrest via the JNK Signaling Pathway in HCC Cells. To further investigate whether JNK plays a role in reducing the expression of $\beta$-catenin and cyclin
D1, HepG2 cells were pretreated with SP600125 $(10 \mu \mathrm{M})$ for $1 \mathrm{~h}$ and then incubated with Huaier extract $(8 \mathrm{mg} / \mathrm{mL})$ for $48 \mathrm{~h}$. Using Western blotting assay, it was found that treatment with either Huaier extract $(8 \mathrm{mg} / \mathrm{mL})$ or SP600125 $(10 \mu \mathrm{M})$ reduced $\beta$-catenin protein levels by $19 \%$ and $28.4 \%$ and cyclin D1 protein levels by $41 \%$ and $51.7 \%$, respectively, and that combination treatment reduced $\beta$-catenin and cyclin D1 protein levels by $54.7 \%$ and $60.7 \%$. These data suggest that Huaier suppresses the expression of $\beta$-catenin and cyclin D1 through the downregulation of JNK signaling in HepG2 cells. Moreover, in a functional assay of cycle inhibitory properties, SP600125 also increased the percentage of HepG2 cells in the $S$ phase, decreased the percentage of cells in the G0/G1 phase, and facilitated the Huaier extract induced $S$ phase arrest in HepG2 cells (Figure 8). All these results indicate that Huaier extract suppresses HCC cells growth by inducing $S$ phase cell cycle arrest through JNK signaling pathway.

\section{Discussion}

Huaier electuary ointment, of which the active ingredient is extracted from fungi of Huaier, has been used in clinic for the treatment of hepatocellular carcinoma with satisfactory results [26]. It has been showed that Huaier extract inhibits the proliferation and tumor angiogenesis and induces apoptosis of hepatocellular carcinoma cells [17]. Additionally, Huaier extract has also been indicated to suppress 

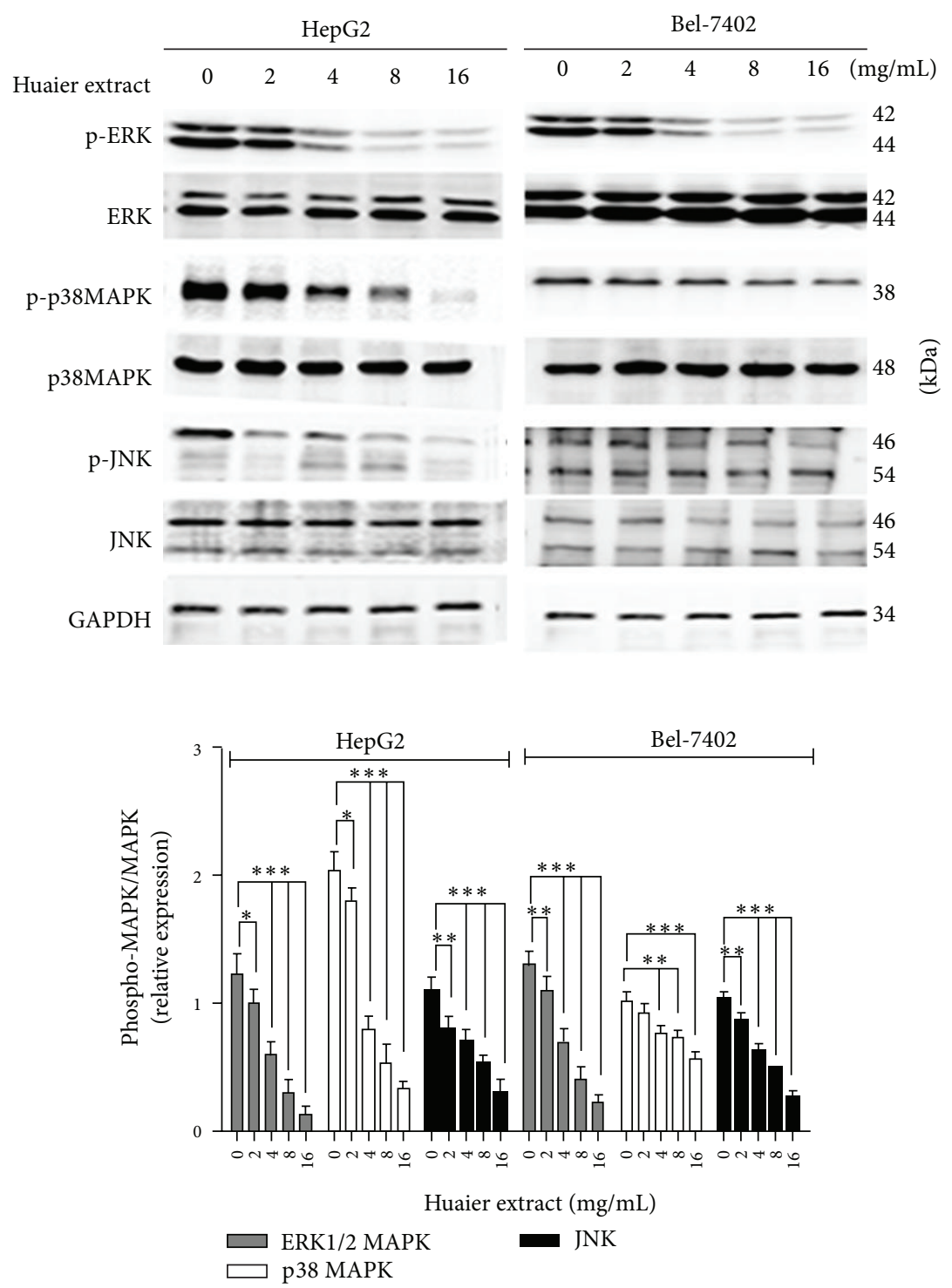

FIGURE 7: Effects of Huaier extract on expression of MAPK in HCC cells. HCC cells were treated with various concentrations $(0,2,4,8$, and $16 \mathrm{mg} / \mathrm{mL}$ ) of Huaier extract for $48 \mathrm{~h}$, and then cell lysates were subjected to Western blotting using respective antibodies against MAPKs. Total ERK1/2, p38, JNK, and GAPDH were included as the loading controls, and the results are expressed as the mean densitometric ratios \pm SD in three independent experiments. ${ }^{*} P<0.05,{ }^{* *} P<0.01$, and ${ }^{* * *} P<0.001$, compared with that of the untreated control, respectively $(0 \mathrm{mg} / \mathrm{mL})$.

the hepatocellular carcinoma biological activities of adhesion, migration, and invasion related to epithelial-mesenchymal transition (EMT) [16]. All these findings provide a certain rationale for therapeutic properties of Huaier extract in clinical applications of hepatocellular carcinoma. However, the potential molecular mechanisms are still elusive and require further validation.

In the current study, the results of MTS assay demonstrated that Huaier extract significantly attenuated the proliferation of HCC cells in a dose-dependent manner. To our knowledge, the inhibition of cell proliferation was involved in apoptosis and block of cell cycle progression. It has been reported that Huaier extract induced melanoma cells and breast cancer cells apoptosis via the increased expression of
$\mathrm{P} 53$ and the modulation of $\mathrm{Bcl}-2 / \mathrm{BAX}$ protein expression $[13$, 18]. Moreover, Huaier extract also caused apoptosis in lung cancer cells via a miR-26b-5p-EZH2-mediated approach [11]. Ren et al. reported that Huaier extract induced HepG2 cells apoptosis by the detection of flow cytometry [17]. However, little is known on the exact apoptosis mechanism of Huaier extract on HCC cells. Of note, our data ascertained that Huaier extract induces the onset of apoptosis by activating caspase 3, increasing the expression of cleaved caspase 3 and cleaved PARP in HCC cells.

Eukaryotic cell proliferation is primarily regulated by the cell cycle, which consists of four phases: the G1 phase, the $S$ phase, the G2 phase, and the $M$ phase [27]. It is well established that the loss of key cell cycle checkpoints 


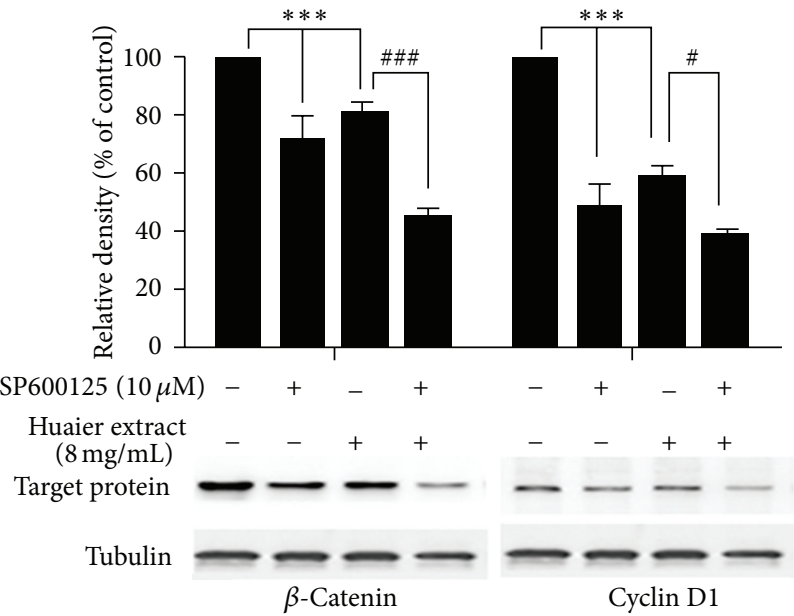

(a)
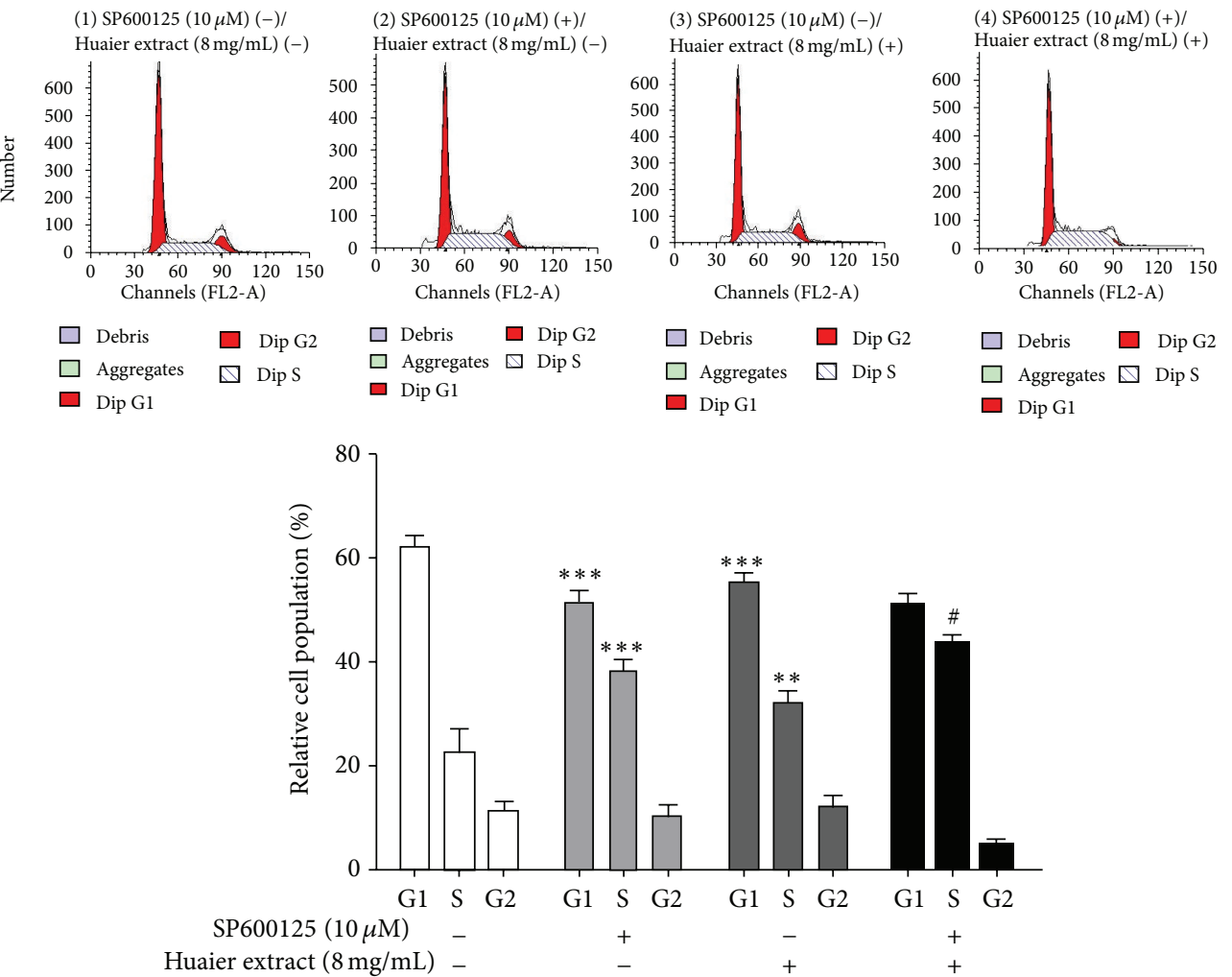

(b)

FIGURE 8: Effect of Huaier extract on the expression of $\beta$-catenin and cyclin D1, as well as cell cycle and inhibition after being treated with a JNK inhibitor (SP600125). (a) HepG2 cells were pretreated with SP600125 $(10 \mu \mathrm{M})$ for $1 \mathrm{~h}$ and then incubated in the presence or absence of Huaier extract $(8 \mathrm{mg} / \mathrm{mL})$ for $48 \mathrm{~h}$. $\beta$-catenin and cyclin D1 protein was determined by using Western blotting. (b) Cells were also assessed by cell cycle. Data are presented as the means \pm SD of at least three independent experiments. ${ }^{* *} P<0.01,{ }^{* * *} P<0.001$, untreated cells versus SP600125 or Huaier extract; ${ }^{\#} P<0.05,{ }^{\# \# \#} P<0.001$ Huaier extract versus SP600125 plus Huaier extract.

is a hallmark of cancer cells, which leads to abnormal proliferation and facilitates oncogenic transformation [28]. The G1/S transition is one of the two predominant checkpoints of the cell cycle and is responsible for the initiation and completion of DNA replication. The majority of studies have reported perturbation of the S/G2 phase transition with a decrease of cells in the G0/G1 phase of the cell cycle and an increase of cells in the $S$ phase $[28,29]$. In the present study, FACS analysis with PI staining revealed that the percentage proportion was increased in the $S$ phase cells and reduced in the G0/G1 phase cells following Huaier extract treatment in a dose-dependent manner, indicating that the inhibitory effect 
of Huaier extract on HCC cell proliferation is mediated by $S$ phase cell cycle arrest.

In the current study, the expression of the important cycle regulatory protein, cyclin D1, and its upstream effector $\beta$-catenin were analyzed following the treatment of HepG2 and Bel-7402 cells with Huaier extract and the results were consistent with previous observations that $S$ phase arrest is accompanied by the decreased expression of cyclin D1 and $\beta$-catenin $[30,31]$. The modifications of these cell cycleassociated proteins induced by Huaier extract appear to block the cell progression through the $S$ phase.

Activated MAPK pathways play a central role in HCC proliferation and cell cycle development [32,33]. However, there are no reports and literatures of the relevant studies illustrating the relationship between Huaier extract and MAPK pathways on the proliferation of HCC. Therefore, we investigated the effect of Huaier extract on MAPK pathways in HCC cells and found that Huaier extract significantly downregulated the phosphorylation of ERK, p38MAPK, and JNK in HepG2 and Bel-7402 cells in a dose-dependent manner. What is more, we further investigated the role of JNK on cell cycle distribution and cycle related protein expression of cyclin D 1 and $\beta$-catenin. Noticeably, treatment with SP600125 obviously decreased expression of cyclin D1 and $\beta$-catenin and also caused a significant increase in the percentage of cells in $S$ phase and decrease in the percentage of cells in the G0/G1 phase, which was consistent with the treatment of Huaier extract on cells. All these results demonstrate that Huaier extract induces hepatocellular carcinoma cells arrest in S phase via JNK signaling pathway.

Overall, our findings verify that Huaier extract causes HCC cell apoptosis and induces hepatocellular carcinoma cells arrest in S phase via JNK signaling pathway, which advances our understanding on the molecular mechanisms of Huaier extract in hepatocarcinoma management. The clinical treatment for liver cancer is difficult due to its malignant biological characteristics such as invasion, metastasis, and malignant proliferation. In this study, we explored the antiproliferative mechanisms of Huaier extract on HCC cells, providing a novel prospect for liver cancer treatment. Huaier extract serves as a promising therapeutic drug for liver cancer, not only for a potent apoptosis inducing, antiangiogenic, and anti-invasive agent, but also for the block role in cell cycle progression.

\section{Conflict of Interests}

The authors declare no conflict of interests.

\section{Acknowledgment}

The present study was supported by the science and technology project of Shenyang (Grant no. F13-212-9-00).

\section{References}

[1] A. Jemal, F. Bray, M. M. Center, J. Ferlay, E. Ward, and D. Forman, "Global cancer statistics," CA Cancer Journal for Clinicians, vol. 61, no. 2, pp. 69-90, 2011.
[2] L. Li, J. Zhang, X. Liu, X. Li, B. Jiao, and T. Kang, "Clinical outcomes of radiofrequency ablation and surgical resection for small hepatocellular carcinoma: a meta-analysis," Journal of Gastroenterology and Hepatology, vol. 27, no. 1, pp. 51-58, 2012.

[3] S. V. G. Nair, M. Hettihewa, and H. P. V. Rupasinghe, "Apoptotic and inhibitory effects on cell proliferation of hepatocellular carcinoma HepG2 cells by methanol leaf extract of Costus speciosus," BioMed Research International, vol. 2014, Article ID 637098, 10 pages, 2014.

[4] R. Wu, L. Duan, L. Ye et al., "S100A9 promotes the proliferation and invasion of HepG2 hepatocellular carcinoma cells via the activation of the MAPK signaling pathway," International Journal of Oncology, vol. 42, no. 3, pp. 1001-1010, 2013.

[5] Z.-J. Dai, W. Tang, W.-F. Lu et al., "Antiproliferative and apoptotic effects of $\beta$-elemene on human hepatoma HepG2 cells," Cancer Cell International, vol. 13, no. 1, article 27, 2013.

[6] X. Wang, N. Zhang, Q. Huo, and Q. Yang, "Anti-angiogenic and antitumor activities of Huaier aqueous extract," Oncology Reports, vol. 28, no. 4, pp. 1167-1175, 2012.

[7] A. Vickers, "Botanical medicines for the treatment of cancer: rationale, overview of current data, and methodological considerations for Phase I and II trials," Cancer Investigation, vol. 20, no. 7-8, pp. 1069-1079, 2002.

[8] K. Shen, L. Ji, B. Lu et al., "Andrographolide inhibits tumor angiogenesis via blocking VEGFA/VEGFR2-MAPKs signaling cascade," Chemico-Biological Interactions, vol. 218, pp. 99-106, 2014.

[9] L. Li, S. Ye, and Y. Wang, "Progress on experimental research and clinical application of Trametes robiniophila," China Cancer, vol. 16, pp. 110-113, 2006.

[10] Y. Guo, P. Cheng, and Y. Chen, "Isolation and analysis of the polysaccharide of Huaier mycelium," Chinese Journal of Biochemical Pharmaceutics, vol. 63, pp. 56-59, 1993.

[11] T. Wu, W. Chen, S. Liu et al., "Huaier suppresses proliferation and induces apoptosis in human pulmonary cancer cells via upregulation of miR-26b-5p," FEBS Letters, vol. 588, no. 12, pp. 2107-2114, 2014.

[12] X. Wang, N. Zhang, Q. Huo, M. Sun, S. Lv, and Q. Yang, "Huaier aqueous extract suppresses human breast cancer cell proliferation through inhibition of estrogen receptor $\alpha$ signaling," International Journal of Oncology, vol. 43, no. 1, pp. 321-328, 2013.

[13] F. Zhang, Z. Zhang, and Z. Liu, "Effects of Huaier aqueous extract on proliferation and apoptosis in the melanoma cell line A875," Acta Histochemica, vol. 115, no. 7, pp. 705-711, 2013.

[14] T. Zhang, K. Wang, J. Zhang et al., "Huaier aqueous extract inhibits colorectal cancer stem cell growth partially via downregulation of the Wnt/ $\beta$-catenin pathway," Oncology Letters, vol. 5, no. 4, pp. 1171-1176, 2013.

[15] X. Yan, T. Lyu, N. Jia, Y. Yu, K. Hua, and W. Feng, "Huaier aqueous extract inhibits ovarian cancer cell motility via the AKT/GSK3 $\beta / \beta$-catenin pathway," PLoS ONE, vol. 8, no. 5, Article ID e63731, 2013.

[16] J. Zheng, C. Li, X. Wu et al., "Huaier polysaccharides suppresses hepatocarcinoma MHCC97-H cell metastasis via inactivation of EMT and AEG-1 pathway," International Journal of Biological Macromolecules, vol. 64, pp. 106-110, 2014.

[17] J. Ren, C. Zheng, G. Feng et al., "Inhibitory effect of extract of fungi of Huaier on hepatocellular carcinoma cells," Journal of Huazhong University of Science and Technology, vol. 29, no. 2, pp. 198-201, 2009. 
[18] J.-H. Cho, J.-G. Lee, Y.-I. Yang et al., "Eupatilin, a dietary flavonoid, induces G2/M cell cycle arrest in human endometrial cancer cells," Food and Chemical Toxicology, vol. 49, no. 8, pp. 1737-1744, 2011.

[19] H. Z. Lee, H. W. C. Leung, M. Y. Lai, and C. H. Wu, "Baicalein induced cell cycle arrest and apoptosis in human lung squamous carcinoma CH27 cells," Anticancer Research, vol. 25, no. 2A, pp. 959-964, 2005.

[20] G. He, J. Kuang, A. R. Khokhar, and Z. H. Siddik, "The impact of S- and G2-checkpoint response on the fidelity of G1arrest by cisplatin and its comparison to a non-cross-resistant platinum(IV) analog," Gynecologic Oncology, vol. 122, no. 2, pp. 402-409, 2011.

[21] D. O. Morgan, "Principles of CDK regulation," Nature, vol. 374, no. 6518, pp. 131-134, 1995.

[22] M. C. Casimiro, M. Velasco-Velázquez, C. Aguirre-Alvarado, and R. G. Pestell, "Overview of cyclins D1 function in cancer and the CDK inhibitor landscape: past and present," Expert Opinion on Investigational Drugs, vol. 23, no. 3, pp. 295-304, 2014.

[23] O. Tetsu and F. McCormick, " $\beta$-catenin regulates expression of cyclin D1 in colon carcinoma cells," Nature, vol. 398, no. 6726, pp. 422-426, 1999.

[24] L. Trusolino and P. M. Comoglio, "Scatter-factor and semaphorin receptors: cell signalling for invasive growth," Nature Reviews Cancer, vol. 2, no. 4, pp. 289-300, 2002.

[25] M. J. Martín, N. Calvo, A. R. de Boland, and C. Gentili, "Molecular mechanisms associated with PTHrP-induced proliferation of colon cancer cells," Journal of Cellular Biochemistry, vol. 115, no. 12, pp. 2133-2145, 2014.

[26] N. Zhang, X. Kong, S. Yan, C. Yuan, and Q. Yang, "Huaier aqueous extract inhibits proliferation of breast cancer cells by inducing apoptosis," Cancer Science, vol. 101, no. 11, pp. 23752383, 2010.

[27] W. Huang, L. N. Yuan, and H. Wu, "Retrospective cohort study on clinical value of Huaier granule in postoperative patients with liver transplantation for hepatocellular carcinoma," Chinese Journal of Bases and Clinics in General Surgery, vol. 17, pp. 547-551, 2010.

[28] W. Lin, L. Zheng, Q. Zhuang et al., "Spica Prunellae extract inhibits the proliferation of human colon carcinoma cells via the regulation of the cell cycle," Oncology Letters, vol. 6, no. 4, pp. 1123-1127, 2013.

[29] J. Pan, M. She, Z.-X. Xu, L. Sun, and S.-C. J. Yeung, "Farnesyltransferase inhibitors induce DNA damage via reactive oxygen species in human cancer cells," Cancer Research, vol. 65, no. 9, pp. 3671-3681, 2005.

[30] F. Wolter, B. Akoglu, A. Clausnitzer, and J. Stein, "Downregulation of the cyclin D1/Cdk4 complex occurs during resveratrolinduced cell cycle arrest in colon cancer cell lines," The Journal of Nutrition, vol. 131, no. 8, pp. 2197-2203, 2001.

[31] W. Ma, R. Liu, J. Qi, and Y. Zhang, "Extracts of centipede Scolopendra subspinipes mutilans induce cell cycle arrest and apoptosis in A375 human melanoma cells," Oncology Letters, vol. 8, no. 1, pp. 414-420, 2014.

[32] H. Wang, H. M. Zhang, H. J. Yin, and et al, "Combination of a novel photosensitizer DTPP with $650 \mathrm{~nm}$ laser results in efficient apoptosis, arresting cell cycle and cytoskeleton protein changes in lung cancer A549 cells," Lasers in Medical Science, 2014.

[33] G. Huang, B. Tang, K. Tang et al., "Isoquercitrin inhibits the progression of liver cancer in vivo and in vitro via the MAPK signalling pathway," Oncology Reports, vol. 31, no. 5, pp. 23772384, 2014. 


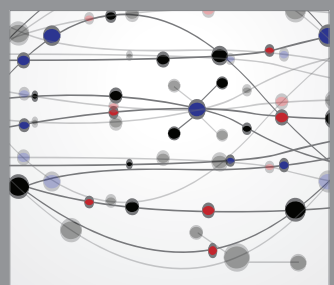

The Scientific World Journal
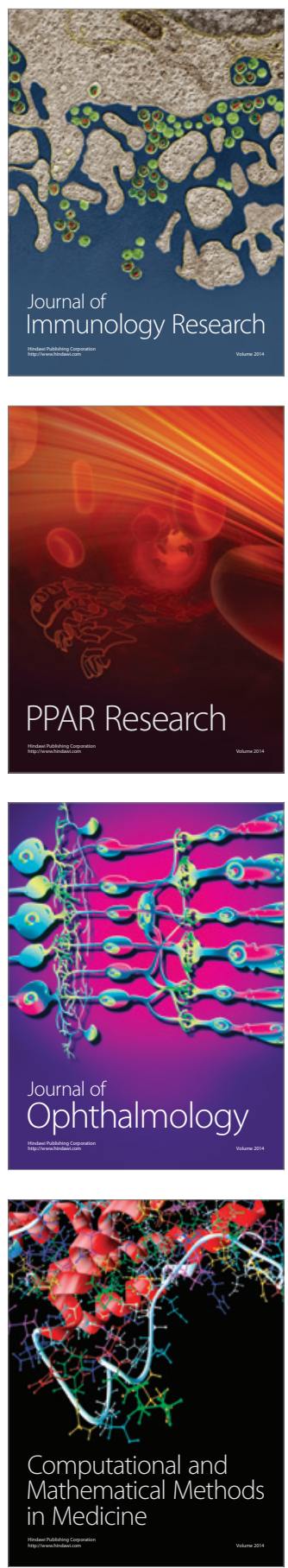

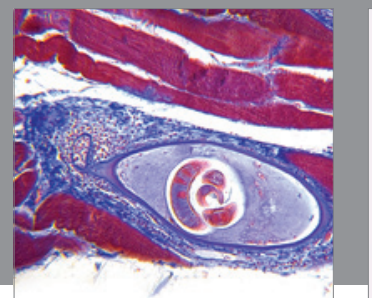

Gastroenterology

Research and Practice
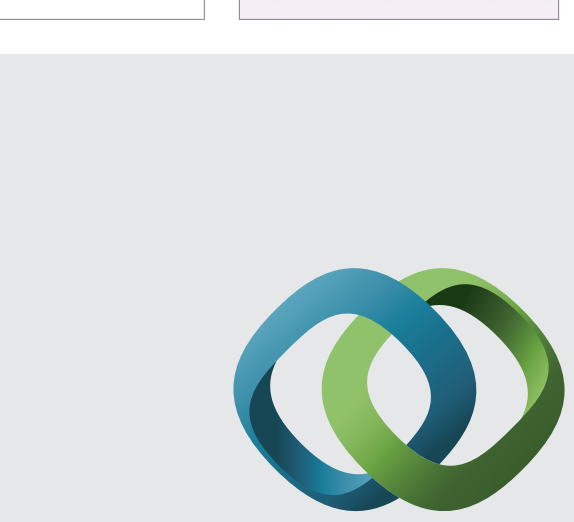

\section{Hindawi}

Submit your manuscripts at

http://www.hindawi.com
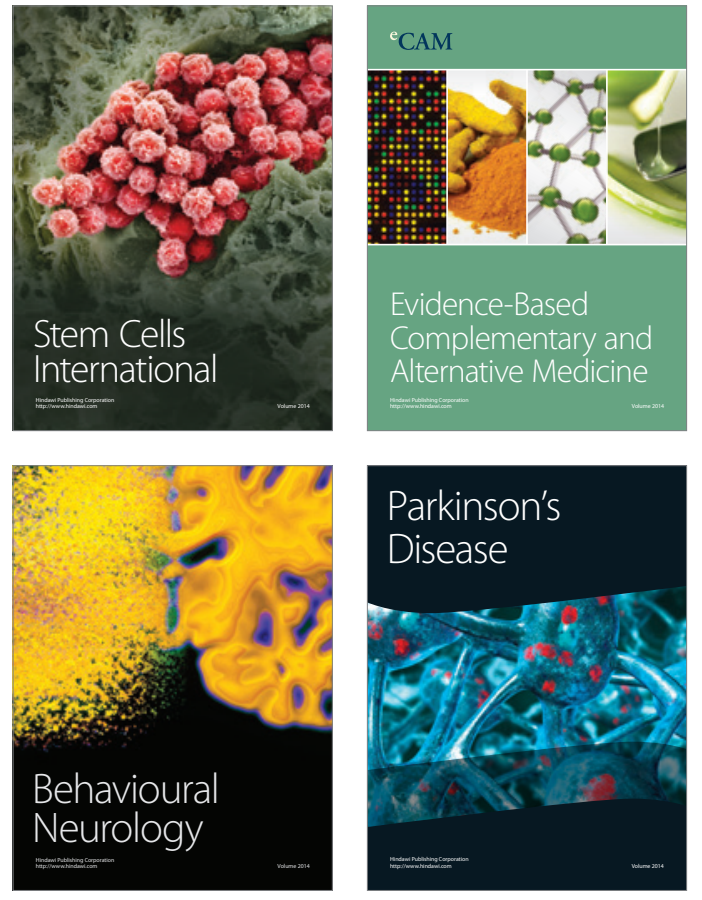
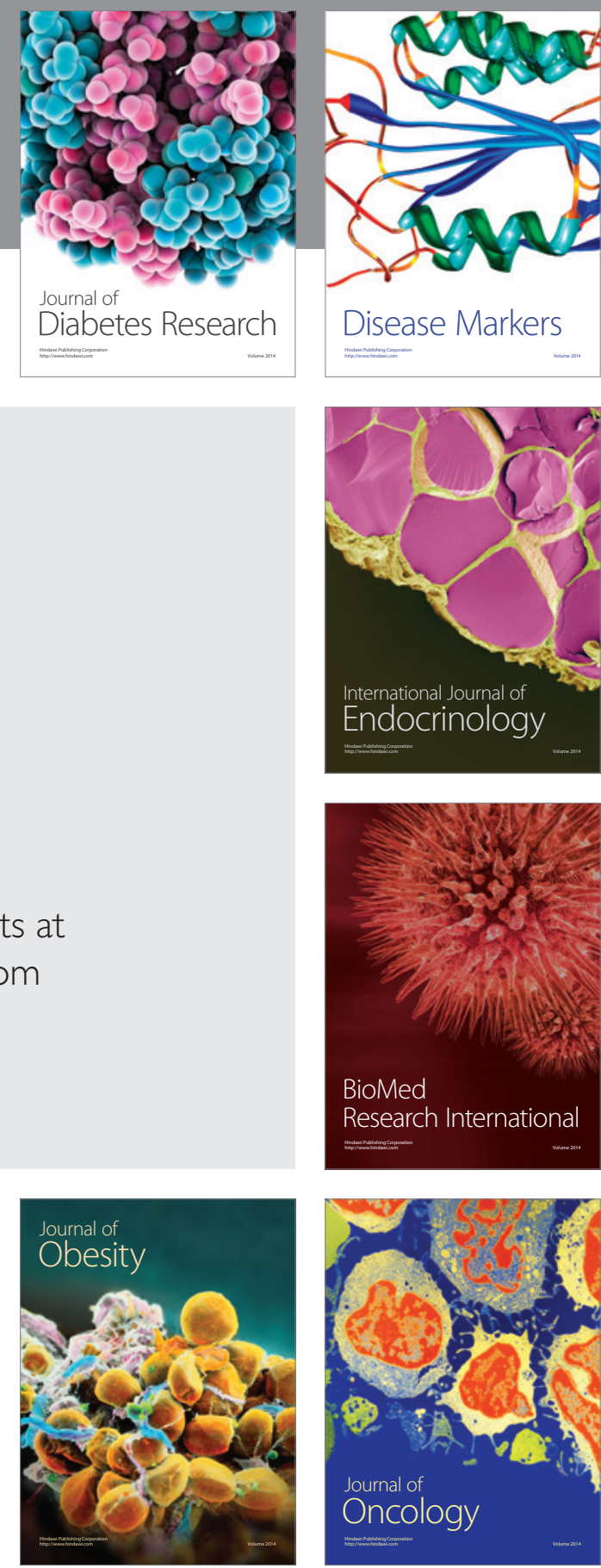

Disease Markers
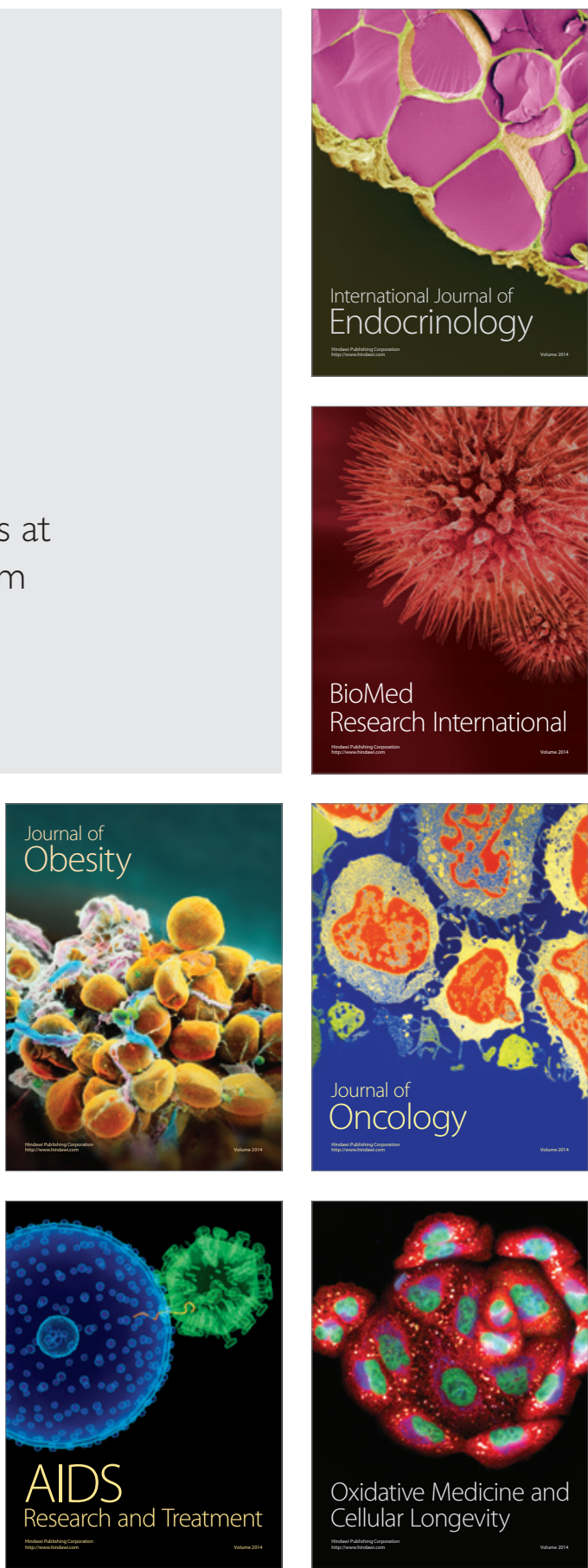